Volume 3 Nomor 1, Halaman 1-81, Januari-Juni 2018

RISTEKDIK | Jurnal Bimbingan dan Konseling

P-ISSN: 2527-4244, E-ISSN : 2541-206X

\title{
Peningkatan Hasil Belajar dengan Penggunaan Benda Asli Pada Mata Pelajaran Sains Sub Pokok Bahasan Bagian - bagian Utama Tumbuhan pada Siswa Kelas II B SD Negeri 200118 Sadabuan PadangsidimpuanTahun Pelajaran 2016/2017
}

\author{
Hj. LIHON PANJAITAN, S.Pd.SD \\ NIP. 196002011979092002. \\ Email : lihonpanjaitan@gmail.com
}

\section{abstrak}

Tujuan penelitian ini adalah untuk mengatahui Apakah benda asli dapat meningkatkan hasil belajar siswa pada mata pelajaran sains sub pokok bahasan Bagian-bagian Utama Tumbuhan di kelas II B SD Negeri 200118 Sadabuan Padangsidimpuan Tahun Pelajaran 2016/2017.

Jenis penelitian ini adalah penelitian tindakan kelas dengan benda asli. Dimana penelitian ini berupaya memaparkan pengaruh penggunaan benda asli terhadap hasil bbelajar siswa pada mata pelajaran Sains (IPA) dengan sub pokok bahasan bagian-bagian utama tumbuhan dikalas II B SD Negeri 200118 Sadabuan PadangsidimpuanTahun Pelajaran 2016/2017.

Subjek penelitian dalam penelitian tindakan kelas adalah siswa di kelas II SD Negeri 200118 Sadabuan Padangsidimpuan Tahun Pelajaran 2016/2017 yang berjumlah 33 orang. Penetapan kelas ini diambil berdasarkan dari hasil obeservsi terhadap kelas yang akan diteliti dan saran dari kepala sekolah SD tersebut.

Berdasarkan hasil penelitian, nilai rata-rata kelas pada pre-test adalah 56,36 dan siswa yang tuntas belajar hanya 14 orang $(42,43 \%)$. Pada post-test siklus I nilai rata-rata siswa adalah 69,39 dan siswa yang tuntas belajar meningkat menjadi 24 orang siswa $(72,73 \%)$. Pada post-test siklus II nilai rata-rata kelas adalah 79,39 dan siswa yang tuntas belajar meningkat menjadi 30 orang siswa $(90,90 \%)$. Siswa yang belum tuntas adalah 3 orang siswa $(9,10 \%)$. Berdasarkan hasil penelitian diperoleh peningkatan hasil belajar. Peningkatan hasil belajar tersebut dapat dibuktikan dari meningkatnya nilai siswa dari pre-test, post-test siklus I dan post-test siklus II. Hasil test belajar inilah yang menunjukkan bahwa kemampuan dan pemahaman siswa dalam mempelajari IPA khususnya pokok bahasan jenis-jenis tanah. Pembelajaran dengan menggunakan benda asli dapat meningkatkan hasil belajar siswa dalam mempelajari pokok bahasan jenis-jenis tanah.

Kata Kunci: hasil helaiar. henda asli nada.

\section{PENDAHULUAN}

Proses mendidik adalah suatu kegiatan yang meneruskan dan mengembangkan nilai-nilai hidup, mengajar berarti meneruskan dan mengembangkan ilmu-ilmu pengetahuan dan teknologi. Seorang guru atau pendidik mengajar sesuai dengan kurikulum yang berlaku di sekolah, inti pelaksanaan pendidikan di sekolah adalah kegiatan belajar mengajar. Menentukan kesuksesan guru dan sekolah ditunjukkan oleh kegiatan belajar mengajar di kelas. Agar situasi kegiatan belajar mengajar menjadi optimal maka guru harus mengetahui situasi dimana siswa dapat berinteraksi dengan guru dan bahkan pembelajaran di tempat yang telah diatur dalam rangka mencapai tujuan.
Guru harus menguasai pengetahuan dan memahami isi materi pelajaran serta pokok bahasan yang diajarkan di kelas, guru harus terampil menggunakan media pembelajaran. Disamping itu, guru mampu mengelola kelas, menerangkan materi pelajaran secara jelas, mengajukan pertanyaan yang berbobot kepada siswa yang sesuai dengan taraf pemahaman siswa dan memonitor serta menilai proses dan hasil belajar. Dalam setiap proses belajar mengajar ditandai dengan adanya beberapa unsur antara lain:tujuan, bahan, metode, media, serta evaluasi. Unsur metode dan media merupakan unsur peraga yang tidak dapat dilepaskan dari unsur lainnya yang berfungsi sebagai cara atau teknik untuk mengantarkan bahan pelajaran agar sampai kepada tujuan pembelajaran. 
Observasi yang pernah saya lakukan di peranan benda asli sebagai media pembelajaran SD, pada waktu KBM (Kegiatan Belajar sangat membantu siswa, sehingga siswa lebih Mengajar) terutama mata pelajaran sains, guru mudah untuk memahami materi. Dalam proses sering memberikan materi pelajaran yang bersifat belajar mengajar benda asli dipergunakan dengan verbalisme (guru terlalu banyak memberikan tujuan membantu guru agar proses belajar siswa penjelasan isi materi) atau lebih menggunakan lebih efektif dan efisien. Dengan menggunakan metode ceramah. Cara mengajar seperti ini benda asli membawa dampak yang positif dalam hanya terpusat pada guru. Aktivitas siswa hanya proses pembelajaran, dimana hubungan antara mendengarkan penjelasn guru dan mencatat hal - guru dan siswa dapat berlangsung lebih interaktif, hal yang dianggap penting. Guru dalam karena dengan benda asli dapat membangkitkan memberikan materi pelajaran hanya dengan cara motovasi dan rangsangan kegiatan terhadap menjelaskan dan memberikan contoh siswa.

menggunakan peta konsep. Guru kurang memotivasi siswa, guru asyik sendiri menjelaskan materi didepan kelas tanpa harus melibatkan siswa dengan cara memperagakan benda asli kepada siswa, guru sering menyuruh siswa untuk mencatat hal-hal yang dianggap pneting didalam materi pelajaran yang disampaikan oleh guru.

Cara guru mengajar dan memberikan materi seperti ini membuat siswa banyak berkhayal di kelas, cepat bosan dan cepat lupa. Karena tidak ada kreativitas seorang guru untuk menggunakan benda asli dalam belajar. Sehingga dengan cara guru memberikan materi pelajaran tidak menggunakan benda asli membuat hasil belajar menjadi rendah. Benda asli adalah alat yang digunakan dalam pembelajaran dengan mengikut sertakan berbagai indera dalam belajar. Ini disebabkan karena benda asli mempunyai ukuran besar, berat, warna di samping keasliannya.

Salah satu materi pelajaran sains yang terdapat pada kurikulum di kelas II SD semester 1 (satu) yaitu bagian-bagian utama tumbuhan. Untuk mengajarkan materi sebaiknya menggunakan benda asli seperti : tanaman tomat, macam-macam daun dan macam-macam akar pada tumbuhan.

Selain itu guru juga menambah dengan media gambar seperti : gambar tanaman tomat, gambar macam-macam daun, gambar macammacam akar pda tumbuhan, gambar keadaan lingkungan dan gambar perabot rumah tangga.

Penggunaan benda asli dalam pembelajaran memegang peranan penting sebagai alat bantu untuk menciptakan kegiatan pembelajaran yang efektif. Karena dapat mendorong motivasi dan meningkatkan hasil prestasi belajar sisiwa. Dalam pencapaian tujuan,

Melihat pentingnya penggunaan benda asli sebagai media pembelajaran sains, penulis tertarik mengadakan penelitian yang berjudul “ Peningkatan Hasil Belajar dengan Penggunaan Benda Asli Pada Mata Pelajaran Sains Sub Pokok Bahasan Bagian - bagian Utama Tumbuhan pada Siswa Kelas II B SD Negeri 200118 Sadabuan Padangsidimpuan Tahun Pelajaran 2016/2017

\section{METODE PENELITIAN}

Jenis penelitian ini adalah penelitian tindakan kelas dengan benda asli. Dimana penelitian ini berupaya memaparkan pengaruh penggunaan benda asli terhadap hasil belajar siswa pada mata pelajaran Sains (IPA) dengan sub pokok bahasan bagian-bagian utama tumbuhan di kelas II B SD Negeri 200118 Sadabuan Padangsidimpuan Tahun Pelajaran 2016/2017.

Penelitian ini dilaksanakan di SD Negeri 200118 Sadabuan Padangsidimpuan. Waktu Penelitian dilaksanakaan selama 3 minggu pada bulan Oktober tahun 2016.

Subjek penelitian dalam penelitian tindakan kelas adalah siswa di Kelas II B SD Negeri 200118 Sadabuan Padangsidimpuan Tahun Pelajaran 2016/2017 yang berjumlah 33 orang. Penetapan kelas ini diambil berdasarkan dari hasil obeservsi terhadap kelas yang akan diteliti dan saran dari kepala sekolah SD tersebut.

\section{HASIL PENELITIAN}

1. Deskripsi Hasil Pelaksanaan Tes Awal

Pada pertemuan awal siswa diberikan pre-test sebelum diberikan tindakan untuk mengetahui kemampuan awal siswa pada pokok bahasan bagian-bagian utama tumbuhan. Dari 
hasil pre-test siswa diperoleh kesimpulan bahwa siswa kurang paham terhadap pokok bahasan bagian-bagian utama tumbuhan. Hasil belajar siswa pada test awal dapat dilihat pada tabel dibawah ini.

\section{Tabel 1}

\section{Hasil Pre-Test Siswa}

\begin{tabular}{|c|c|c|c|c|}
\hline No & No.Responden & Skor & Nilai & Kriteria \\
\hline 1 & Abdul Rahman & 7 & 70 & Tuntas \\
\hline 2 & Aisah Putri & 5 & 50 & $\begin{array}{c}\text { Tidak } \\
\text { Tuntas }\end{array}$ \\
\hline 3 & $\begin{array}{l}\text { Aiyla Azzura } \\
\text { Harahap }\end{array}$ & 4 & 40 & $\begin{array}{l}\text { Tidak } \\
\text { Tuntas }\end{array}$ \\
\hline 4 & Aldo & 7 & 70 & Tuntas \\
\hline 5 & $\begin{array}{l}\text { Annisa Putri } \\
\text { Ritonga }\end{array}$ & 5 & 50 & $\begin{array}{c}\text { Tidak } \\
\text { Tuntas } \\
\end{array}$ \\
\hline 6 & Arif Alwi Rambe & 7 & 70 & Tuntas \\
\hline 7 & $\begin{array}{l}\text { Arif Setia } \\
\text { Paruhumdly }\end{array}$ & 5 & 50 & $\begin{array}{l}\text { Tidak } \\
\text { Tuntas }\end{array}$ \\
\hline 8 & $\begin{array}{l}\text { Arizty Gihna } \\
\text { Rambe }\end{array}$ & 4 & 40 & $\begin{array}{l}\text { Tidak } \\
\text { Tuntas }\end{array}$ \\
\hline 9 & Armansyah Putra & 7 & 70 & Tuntas \\
\hline 10 & Aukia Romaito & 4 & 40 & $\begin{array}{c}\text { Tidak } \\
\text { Tuntas } \\
\end{array}$ \\
\hline 11 & Dian Nanda Lestari & 8 & 80 & Tuntas \\
\hline 12 & Fauzan & 4 & 40 & $\begin{array}{c}\text { Tidak } \\
\text { Tuntas }\end{array}$ \\
\hline 13 & Fiqri Hardani & 7 & 70 & Tuntas \\
\hline 14 & $\begin{array}{l}\text { Israini Zahra } \\
\text { Hasibuan }\end{array}$ & 5 & 50 & $\begin{array}{c}\text { Tidak } \\
\text { Tuntas }\end{array}$ \\
\hline 15 & Jahrona Siregar & 7 & 70 & Tuntas \\
\hline 16 & Muammar Siregar & 4 & 40 & $\begin{array}{l}\text { Tidak } \\
\text { Tuntas }\end{array}$ \\
\hline 17 & $\begin{array}{l}\text { Muhammad } \\
\text { Ibrahim Hrp }\end{array}$ & 4 & 40 & $\begin{array}{l}\text { Tidak } \\
\text { Tuntas }\end{array}$ \\
\hline 18 & Nazifa Amanda & 8 & 80 & Tuntas \\
\hline 19 & Nur Hikmah Putri & 5 & 50 & $\begin{array}{c}\text { Tidak } \\
\text { Tuntas }\end{array}$ \\
\hline 20 & Putri Hajjani & 7 & 70 & Tuntas \\
\hline 21 & Rezky Roihan & 7 & 70 & Tuntas \\
\hline 22 & Ridho Mhd Akhir & 5 & 50 & $\begin{array}{c}\text { Tidak } \\
\text { Tuntas } \\
\end{array}$ \\
\hline 23 & Rifani Humairoh & 4 & 40 & $\begin{array}{c}\text { Tidak } \\
\text { Tuntas } \\
\end{array}$ \\
\hline 24 & Riski Ernando & 7 & 70 & Tuntas \\
\hline 25 & $\begin{array}{l}\text { Riska Saputri } \\
\text { Sinaga }\end{array}$ & 4 & 40 & $\begin{array}{c}\text { Tidak } \\
\text { Tuntas }\end{array}$ \\
\hline 26 & Risky Aulia Lubis & 8 & 80 & Tuntas \\
\hline 27 & $\begin{array}{l}\text { Risky Yahya } \\
\text { Pulungan }\end{array}$ & 4 & 40 & $\begin{array}{c}\text { Tidak } \\
\text { Tuntas } \\
\end{array}$ \\
\hline 28 & Sherin Sasmita & 5 & 50 & $\begin{array}{l}\text { Tidak } \\
\text { Tuntas }\end{array}$ \\
\hline 29 & Shifa Ashila & 7 & 70 & Tuntas \\
\hline 30 & Shirta Sura & 5 & 50 & $\begin{array}{c}\text { Tidak } \\
\text { Tuntas } \\
\end{array}$ \\
\hline
\end{tabular}

\begin{tabular}{|c|l|c|c|c|}
\hline 31 & Silvi Sania Ritonga & 4 & 40 & $\begin{array}{c}\text { Tidak } \\
\text { Tuntas }\end{array}$ \\
\hline 32 & $\begin{array}{l}\text { Zaskia Aulia } \\
\text { Ramadhani }\end{array}$ & 7 & 70 & Tuntas \\
\hline 33 & Zahra Tambunan & 5 & 50 & Tidak \\
\hline \multicolumn{4}{|c|}{ Jumlah 1860 } \\
\hline
\end{tabular}

Dari tes awal yang dilakukan yang didapat dari jumlah nilai keseluruhan siswa dengan nilai rata-rata kelas 56,36. Hal ini jelas menunjukkan tingkat penguasaan 14 siswa terhadap pokok bahasan bagian-bagian utama tumbuhan sangat rendah sekali. Hanya ada 14 siswa yang memperoleh nilai diatas 65 dan 19 siswa mendapat nilai 65 kebawah. Persentase menunjukkan :

\section{$\geq 65$ ada 14 siswa $=42,43 \%$ \\ $<65$ ada 19 siswa $=57,57 \%$}

Hasil nilai siswa pada tes awal menunjukkan bahwa siswa masih mengalami kesulitan dalam menyelesaikan soal dan kurang memahami pokok bahasan bagian-bagian utama tumbuhan. Kesulitan diakibatkan:

1) Siswa belum mengetahui bagian-bagian utama tumbuhan dan bentuk serta kegunaannya.

2) Siswa masih salah menjawab pertanyaan dari soal yang diberikan.

Kenampakan hasil test awal siswa dapat dilihat pada tabel 2 dibawah ini:

Tabel 2

\section{Kenampakan Hasil Test Awal Siswa}

\begin{tabular}{|c|c|c|c|}
\hline Nilai & $\mathrm{F}$ & $\%$ & Tingkat \\
\hline $90-100$ & 0 & $0 \%$ & Baik Sekali \\
\hline $80-89$ & 3 & $9.1 \%$ & Baik \\
\hline $70-79$ & 11 & $33.3 \%$ & Sedang \\
\hline $60-69$ & - & - & Sedang \\
\hline $50-59$ & 9 & $27.3 \%$ & Rendah \\
\hline $40-49$ & 10 & $30.3 \%$ & Rendah \\
\hline
\end{tabular}

Berdasarkan tabel dan grafik diatas dapat dilihat nilai tertinggi adalah 80 sebanyak 3 siswa dengan persentase $(9,1 \%)$, yang mendapat nilai 70 sebanyak 11 orang siswa $(33,3 \%)$, siswa yang mendapat nilai 50 sebanyak 9 orang siswa $(27,3 \%)$, siswa yang mendapat nilai 40 sebanyak 
10 orang siswa dengan persentase (30,3\%). Nurkancana, Wayan 1992. Evaluasi Hasil Dengan demikian dinyatakan bahwa hasil pre-test belum tuntas pada pokok bahasan bagian-bagian utama tumbuhan.

\section{KESIMPULAN}

Berdasarkan hasil pembahasan penelitian, maka dapat ditarik kesimpulan sebagai berikut:

1. Berdasarkan hasil penelitian, nilai rata-rata kelas pada pre-test adalah 56,36 dan siswa yang tuntas belajar hanya 14 orang $(42,43 \%)$. Pada post-test siklus I nilai rata-rata siswa adalah 69,39 dan siswa yang tuntas belajar meningkat menjadi 24 orang siswa $(72,73 \%)$.

Belajar. Surabaya Usaha Nasional.

Slameto. 2010. Belajar dan Faktor-Faktor Yang Mempengaruhi. Jakarta: Rineka Cipta.

Samatowa, Usman. 2010. Pembelajaran IPA di Sekolah Dasar. Jakarta : PT Indeks.

Sudjana, N. 2009. Penilaian Hasil Proses Belajar Mengajar. Bandung: Remaja Rosda Karya.

2. Pada post-test siklus II nilai rata-rata kelas adalah 79,39 dan siswa yang tuntas belajar meningkat menjadi 30 orang siswa $(90,90 \%)$. Siswa yang belum tuntas adalah 3 orang siswa $(9,10 \%)$.

3. Berdasarkan hasil penelitian diperoleh peningkatan hasil belajar. Peningkatan hasil belajar tersebut dapat dibuktikan dari meningkatnya nilai siswa dari pre-test, posttest siklus I dan post-test siklus II. Hasil test belajar inilah yang menunjukkan bahwa kemampuan dan pemahaman siswa dalam mempelajari IPA khususnya pokok bahasan bagian-bagian utama tumbuhan. Pembelajaran dengan menggunakan benda asli dapat meningkatkan hasil belajar siswa dalam mempelajari pokok bahasan bagianbagian utama tumbuhan

\section{DAFTAR PUSTAKA}

Arikunto. 2006. Prosedur Penelitian Suatu Pendekatan Praktik. Jakarta: Rineka Cipta.

Arsyad, Azhar. 2002. Media Pembelajaran. Jakarta: Raja Grafindo Persada.

Bundu. Patta. 2006. Penilaian Keterampilan Proses Dan Sikap Ilmiah Dalam Pembelajaran Sains di SD. Depdiknas.

Hasibuan, Bey A. 2002. Cara Belajar yang Efektif. Medan: SLTP Negeri 16.

Haryanto. 2004. Sains Untuk Kelas V SD. Jakarta : Erlangga.

Mudjiono dan Dimyati. 2006. Belajar dan Pembelajaran. Jakarta: Rineka Cipta. 